\title{
The Effectiveness of Criminal Eradication on Hoax Information and Fake News
}

\author{
Hernawan Dewatana*)and Ummu Adillah**) \\ *) Police of Grobogan, E-mail: deta.dewata18@gmail.com \\ $\left.{ }^{* *}\right)$ Faculty of Law Universitas Islam Sultan Agung (UNISSULA) Semarang
}

\begin{abstract}
The rise of hoax informations/ fake news circulating can have a negative impact on the development of the Indonesian state. Hoaxes can cause debates to the point where it is not impossible to break friendships. Moreover, the hoax that contains SARA which is very vulnerable to invite friction between communities, disturbs the stability of the country and diversity. This study aims to determine the effectiveness of law enforcement in cases of spreading false information. The research method is sociological juridical. The basic regulations for the spread of fake news or hoaxes have been regulated in Act No. 11 of 2008 which has been changed to Act No. 19 of 2016 articles 28 paragraphs 1 and 2. It can be charged with other related articles, namely articles 310, 311, 378 and 390 of the Criminal Code. With the rapid development of today's technology, the more diverse and many new crimes committed through electronic media, in this case the spread of fake news (Hoax) which is currently rife. The current regulations related to fake news have regulated not only the creators of the fake news who are given criminal sanctions but also for the perpetrators who participate in sharing (forwarding) the fake news.

Keywords: Effectiveness; Crime; Fake News; Hoax.
\end{abstract}

\section{Introduction}

The integration of the national economy into the world economic system through economic globalization in its development can also weaken national political stability. This is because the occurrence of economic turmoil in developed countries and the world can have an impact on the national economy. In addition, in the current era of globalization where Indonesia's economic dependence on foreign investment has also created vulnerabilities for the stability of the national economy. This is because foreign investors can unilaterally withdraw their investments from the Indonesian capital market. This can spread and lead to distrust of other market players and trigger a rush that leads to a national economic crisis.

The collapse of the national economy was marked by the problem of poverty and the widening gap after the crisis had given rise to various problems surrounding human rights violations in Indonesia. This is shown by the fact that 4.1 million people in Indonesia are uneducated, and this results in 4.1 million people without a job and a decent economic life. ${ }^{1}$ Poverty, inequality, and human rights violations that occur can lead to other problems in national security, namely the issue of terrorism. According to Peter Weiss, terrorism occurs as a result of

\footnotetext{
1"4,1 Juta Anak Indonesia Tidak Sekolah" https://www.minded-rakyat.com/education/pr01281064/41-juta-anak-indonesia-no-school-402455\#: : text=JAKARTA\%2C\%20(PR).,6\%2D21 \%20years\%20no\%20school, Downloaded on May 12, 2021.
} 
injustice received by a group, resulting in the emergence of parties who carry out anarchic actions on the scale of ethnicity, nation, class, or other social groupings. ${ }^{2}$ Furthermore, Checnia added that each region is identified with the expansion of poverty driven by environmental degradation, inconductive business conditions with high levels of corruption and crime. ${ }^{3}$ The forms of terrorism attacks in its development are not only in the form of physical attacks using bombs as one of the main weapons. But developing using nuclear technology, pharmaceutical and food technology, as well as information, communication, and transportation technology. 4

Based on the description above, it can be understood that globalization has had a negative impact on various sectors of life in Indonesia. The negative impact is essentially a threat to Indonesia's national security. The problems above show that as a result of globalization there has been a development of a spectrum of threats ${ }^{5}$ towards national security which does not only cover the military sector but also includes security in the political, economic, socio-cultural, and environmental fields. ${ }^{6}$

One of the existing threats is related to the issue of spreading false information through the mass media. The development of the internet in the world is very fast, including in Indonesia. Especially after the emergence of smart phones (Smartphones). Users also vary, ranging from adults to elementary school children. Also from various economic backgrounds. 3 Internet media is a media that knows no boundaries. Both regional boundaries and state boundaries.

\footnotetext{
${ }^{2}$ Peter Weiss in Agus Wahyudi, Terorisme dan Hukum Internasional, Jurnal Mimbar Hukum, Volume X Nomor 48, Universitas Gadjah Mada, Yogyakarta, 2004, p. 111. According to Nisan Horowitz the definition of terrorism depends on the observer so that there is no absolute definition of what theory is. Ha'aret in Agus Wahyudi, Loc.Cit. Furthermore, Brian Jenkins stated that the term terrorism depends on a person's way or point of view which results in a moral judgment. However, there are several limitations put forward in relation to terrorism, namely: a) justifying the use of violence; b) rejection of the implementation of the political process; c) increasing totalitarianism; and d) rejection of the existence of morality. See: Aulia Rosa Nasution, Terorisme Sebagai Kejahatan Terhadap Kemanusiaan: Dalam Perspektif Hukum Hak Asasi Manusia, Ed.1, Kencana Prenada Media Group, Jakarta, 2012, p. 92-93.

3 D.Linote and M.Yoshii in Daniel Linotte, Economic Aspects of Terrorism, Journal of Central Asia and The Caucasus Regional Politics, No.3(45), 2007, p.124.

${ }^{4}$ Christina Hellmich (2009) Thomas A. Johnson (Ed.): National Security Issues in Science, Law and Technology, Democracy and Security, 5:1, 84-88, p. 84.

${ }^{5}$ The expansion of the threat spectrum in question is regarding the definition of threats that threaten national security at the international, regional, national and regional security levels. Buzan and Hanzen further said that what is clearly visible in a country is that the modern concept of national security is as important as the traditional concept of national security. The concept of national security has traditionally remained the center of study but no longer dominates as a referent object (threat reference object). Thus, securitization actors can generally define that the current national security threat is related to state capabilities and state resources; However, the more they apply in the sovereign space of the state where the spectrum of state security protection is regulated from states to sub-states then becomes inter-state, as a result threats become difficult to measure, monitor, map, and describe. See: Barry Buzan, 1997a:6-21;Klate, 1998 : 66; Nye, 1989; Vayrynen, 1998; Warver et al, 1993 dalam Victor D.Cha, 2000, Globalization and the Study of International Security, Journal of Peace Research, Vol 37, No.3, p. 134.

${ }^{6}$ Berry Buzan, Ole Waever, and Jaap de Wilde, Security A New Framework for Analysis, Lynne Rienner Publisher, United Kingdom, 1998, p. 8-9.
} 
This has both positive and negative impacts on its users. As is known, the rules of behavior adopted by each country are different, so what is allowed to be done freely in one country will be considered a violation of the law in another country, and vice versa. While on the internet there are no national boundaries. For example, an Indonesian internet user who enters a site is no different from a user from another country who enters the same site. As the name WWW, namely the World Wide Web, the internet network is as wide as the world. Laws made to regulate the internet in one country will immediately and automatically enter the jurisdiction of other countries. Of course there will be contradictions, as said above, what is prohibited in Indonesia may be required in other countries

The rise of hoax news circulating can have a negative impact on the development of the Indonesian state. Hoaxes can cause debates to the point where it is not impossible to break friendships. Moreover, the hoax that contains SARA which is very vulnerable to invite friction between people, disturbs the stability of the country and diversity. Hoaxes in the context of reports whose origins are unclear, cannot be ensnared by the Press Law, because it is rather difficult to distinguish between Mainstream Press and Hoax Press. In the New Order era, it was rather easy, because the mainstream press was licensed, while at present the press is without a license, because in Indonesia the obligation to have a Press Publishing Business License (SIUPP) has been abolished. ${ }^{7}$

In its development, the regulation regarding the crime of spreading false information is regulated in Act No. 19 of 2016 concerning Electronic Information and Transactions. Article 27 paragraph (3):

Everyone intentionally, and without rights distributes and/or transmits and/or makes accessible Electronic Information and/or Electronic Documents that contain insults and/or defamation.

Then in Article 28 of Act No.19 of 2016:

1. any person who knowingly and without rights spreads false and misleading news that results in consumer losses in electronic transactions.

2. every person intentionally and without rights disseminates information aimed at causing feelings of hatred or hostility towards certain individuals and/or community groups based on ethnicity, religion, race, and inter-group (SARA).

Based on the sound of the article above, it is clear that there are two forms of criminal acts of Information and Electronic Transactions in article 28, each of which is formulated in paragraph (1) and paragraph (2). The crime of Information and Electronic Transactions in paragraph (1) consists of the following elements:

- Error: on purpose.

- Against the law: without rights

- Action: spread

- Object: fake and misleading news

- Constitutive consequences result in consumer losses in electronic transactions. The criminal elements in paragraph (2) are:

${ }^{7}$ Asril Sitompul, Hukum Internet Pengenalan Mengenai Masalah Hukum di Cyberspace, PT. Citra Aditya Bakti, Bandung , 2004, p.71. 
- Error: intentionally

- Against the law: without rights

- Action: spread

- Object: information

- Purpose: to create feelings of hatred or hostility towards certain individuals and/or groups of people. 9 Act No. 11 of 2008 concerning Information and Electronic Transactions based on ethnicity, religion, race, and inter-group (SARA).

Even though the arrangements related to hoaxes or fake news have been well regulated, in reality hoax cases are still growing. The latest case related to fake news circulating in cyberspace is the lack of fuel due to the burning of Pertamina's oil refinery in Balongan. ${ }^{8}$ Then the Head of the Public Relations Division of the Police Headquarters stated that in in 2020 there are 352 cases that we handle related to hoax cases. ${ }^{9}$

This has clearly resulted in the disruption of national security stability and losses for the community. In this regard, it is necessary to carry out a more indepth discussion regarding this the effectiveness of law enforcement in cases of spreading false information, especially in the Grobogan area.

\section{Research Methods}

The type of research used in this study is a sociological juridical legal research type. The approach uses sociological juridical, the specification in this writing is analytical descriptive. Methods of collecting data by means of field studies and literature studies. Methods of data analysis using qualitative methods.

\section{Result and Discussion}

\subsection{Implementation of handling the crime of spreading false information in Grobogan Regency}

In Act No. 11 of 2008 concerning Information and Electronic Transactions, it is regulated about the spread of false news (hoax) for those who violate the following sanctions: Article 28 paragraph (1), namely the content of false and misleading news, Article 28 paragraph (2), namely: content that causes hatred or hostility to certain individuals and/or community groups based on ethnicity, religion, race, and inter-group (SARA).

And the article related to the provisions of Article 28 paragraph (2) of the Electronic Transaction Information Law still creates multiple interpretations. But in fact, the provisions of the article have been used in resolving many cases that violate the contents of the article. In the implementation of the use of the article in the judiciary, law enforcers, especially judges, must use legal interpretation to

\footnotetext{
${ }^{8}$ https://finance.detik.com/energi/d-5511928/awas-hoax-bbm-langka-imbas-kilang-kebakaranpertamina-stok-luber? ga=2.97229085.383504003.1161711994-2108725843.1615290580, accessed on 12 March 2021.

9 https://www.jawapos.com/nasional/06/02/2021/polri-sepanjang-2020-ada-352-case-hoax/, accessed on 12 March 2021.
} 
provide an understanding that an act has violated the article. The interpretation itself, according to D. Simons, the main requirement for interpreting a statutory regulation is that the regulation must be interpreted based on the statutory regulation itself. In elaborating the interpretation, it is not permissible to look for materials outside the regulation. In fact, 10

That actions that can be categorized as violating the provisions of Article 28 paragraph (2) of the ITE Law, namely, 1) there are parties who feel aggrieved by the actions of a person or group of people related to SARA elements, 2) The act contains pictures of people people who are purified in a religion that is contrary to the original image, 3) Make writings that vilify the contents of the holy book of a religion that is different from the teachings of that religion or, 4) Disseminate personal things that are contrary to or violate the norms of decency and decency, 5) The actions carried out contain elements of SARA and are carried out on social media. ${ }^{11}$

The defendant can only be punished according to this article, if it turns out that the news broadcast is false news. What is seen as false news, not only tells an empty news, but also tells incorrectly about an incident. Raising or lowering the price of goods and so on, by broadcasting false news can only be punished, that the broadcasting of false news is carried out with the intention of benefiting oneself or others. People who increase the price of merchandise or securities by buying on a large scale are not punished. ${ }^{12}$

\subsection{Effectiveness of handling criminal acts of spreading false information in Grobogan Regency}

That there are factors that affect the effectiveness of the implementation of handling the crime of spreading false information in Grobogan Regency are as follows:

\subsubsection{Legal Substance Factor}

The handling of the crime of spreading false news (hoax), in terms of legal substance, is the current Police, referring to Act No. 11 of 2008 concerning Information and Technology, in particular Article 28 paragraph (1) contains that "Everyone intentionally and without rights spreads false and misleading news that results in consumer losses in electronic transactions", in conjunction with Article 28 paragraph (2) contains that " Everyone intentionally and without rights disseminates information aimed at creating feelings of hatred or hostility towards certain individuals and/or community groups based on ethnicity, religion, race, and inter-group (SARA)" or hoax can be done if there are strict legal rules governing it, if only based on Law 19 of 2016 concerning Amendments to Act No. 11 of 2008 concerning ITE, especially Article 27, Article 28 and Article 45, it will be very difficult for the police to deal with it, especially to take action because the ITE Law

\footnotetext{
10 PAF Lamintang, and C. Djisman Samosir, (2010), Delik-delik Khusus Kejahatan yang Ditujukan Terhadap Hak Milik dan lain-lain Hakyang Timbul dari Hak Milik, Bandung: TARSITO Bandung 11 Fransiskus Sebastian Situmorang , (2017), Tinjauan Yuridis Terhadap Ketentuan Pasal 28 ayat 2 UU informasi dan tekhnologi, https://ojs.unud.ac.id 12 Ibid.
} 
is lex specialis, which regulates specifically about ITE, but in the process of dealing with it, strategic police steps are needed which relies on the rule of law, currently the rules governing it are still bound in Articles 55 and 56 of the Criminal Code and articles in the Criminal Procedure Code. ${ }^{13}$

\subsubsection{Factors of Law Enforcement Apparatus}

One of the keys to success in law enforcement is the mentality or personality of the law enforcers themselves. Within the framework of law enforcement and implementation of law enforcement, the enforcement of justice without the truth is a crime. Enforcement of truth without honesty is hypocrisy. In the context of law enforcement by every law enforcement agency, justice and truth must be stated, felt, seen and must be actualized. In an effort to overcome fake news or hoaxes, there are aspects of law enforcement officials related to human resources in police agencies which are still limited in terms of control of ITE, at the level of the Criminal Investigation Agency (Bareskrim) of the National Police Headquarters there is already a special Directorate for ITE crimes, However, at the Regional Police level, they are still members of the Directorate of Special Criminal Investigation (Dirreskrimsus) and at the Resort Police (Polres) level, not all of them have Cyber Special Units, moreover, the police officers have inadequate understanding and knowledge of the cyber world. The Police currently in order to tackle (prevent and take action) perpetrators of spreading false news or hoaxes still rely on collaboration with other institutions or even still use the capabilities of ITE experts outside the police institution, and it takes a long time of coordination related to operational costs. If you look at the human resource capabilities currently owned by the Police, it is still limited to the scope of the Criminal Investigation Unit of the National Police Headquarters in Jakarta, and the Regional Police do not yet specifically have a special task force to deal with cyber crime, let alone at the level of the Resort Police and Polsek ranks, while cyber crimes do not only occur in big cities but can also occur in small cities or villages that have internet access. The ability of personnel (members) who understand or control Information and Electronic Transactions is still limited in the small scope of Polri personnel at the National Police Headquarters and Polda, even personnel at the Resort Police and Polsek do not have special abilities in the ITE field, while personnel who are in contact directly with the community are those at the Resort Police, Polsek up to Bhabinkamtibmas (Bhayangkara Pembina Public Order Security). ${ }^{14}$

\subsubsection{Factors of Facilities and Infrastructure}

Supporting facilities and infrastructure include educated and skilled human resources, good organization, adequate equipment, adequate finances. Without adequate facilities and facilities, law enforcement cannot run smoothly and law enforcers cannot carry out their roles properly. Furthermore, according to that facilities and infrastructure constraints have an influence in efforts to prevent the

\footnotetext{
${ }^{13}$ Firman Rostama Trisna, (2019), Tindakan Hukum Terhadap Penyebaran berita Bohong (Hoax) Di media Sosial, https://maksigama.wisnuwardhana.ac.id

${ }^{14}$ Ibid
} 
prevention of criminal acts of perpetrators of spreading false news (hoax) to the disclosure of perpetrators of spreading false news (hoax), they still have limitations in: Access and coordination with service providers and cellular and internet service providers ; Do not have a special server for digital forensics, as a support for work in the field of Information and Electronic Transactions. ${ }^{15}$

\section{Closing}

The basic regulations for the spread of fake news or hoaxes have been regulated in Act No. 11 of 2008 which has been changed to Act No. 19 of 2016 articles 28 paragraphs 1 and 2 . It can be charged with other related articles, namely articles 310, 311, 378 and 390 of the Criminal Code. With the rapid development of today's technology, the more diverse and many new crimes committed through electronic media, in this case the spread of fake news (Hoax) which is currently rife. The current regulations related to fake news have regulated not only the creators of the fake news who are given criminal sanctions but also for the perpetrators who participate in sharing (forwarding) the fake news.

\section{References}

\section{Journal}

[1] D.Linote and M.Yoshii in Daniel Linotte, Economic Aspects of Terrorism,Journal of Central Asia and The Caucasus Regional Politics, No.3(45), 2007

[2] Firman Rostama Trisna, (2019), Tindakan Hukum Terhadap Penyebaran berita Bohong (Hoax) Di media Sosial, https://maksigama.wisnuwardhana.ac.id

[3] Ilham Panunggal jati Darwin, (2018), Peran Kepolisian dalam penyidikan Tindak Pidana penyebaran Berita Bohong (Hoax), https://jurnal.fh.unila.ac.id

[4] Peter Weiss in Agus Wahyudi, Terorisme dan Hukum Internasional, Jurnal Mimbar Hukum, Volume X Nomor 48, Universitas Gadjah Mada, Yogyakarta, 2004

[5] Warver et al, 1993 in Victor D.Cha, 2000, Globalization and the Study of International Security, Journal of Peace Research, Vol 37, No.3

\section{Books}

[1] Amiruddin, Pengantar Metode Penelitian Hukum, PT. Raja Grafindo Persada, Jakarta, 2012

[2] Asril Sitompul, Hukum Internet Pengenalan Mengenai Masalah Hukum di Cyberspace, PT. Citra Aditya Bakti, Bandung, 2004

[3] Aulia Rosa Nasution, Terorisme Sebagai Kejahatan Terhadap Kemanusiaan: Dalam Perspektif Hukum Hak Asasi Manusia, Ed.1, Kencana Prenada Media Group, Jakarta, 2012

\footnotetext{
15 Ilham Panunggal jati Darwin, (2018), Peran Kepolisian dalam penyidikan Tindak Pidana penyebaran Berita Bohong (Hoax), https://jurnal.fh.unila.ac.id
} 
[4] Berry Buzan, Ole Waever, dan Jaap de Wilde, Security A New Framework for Analysis, Lynne Rienner Publisher, United Kingdom, 1998

[5] Christina Hellmich (2009) Thomas A. Johnson (Ed.): National Security Issues in Science, Law and Technology, Democracy and Security, 5:1

[6] P.A.F. Lamintang, dan C. Djisman Samosir, (2010), Delik-delik Khusus Kejahatan yang Ditujukan Terhadap Hak Milik dan lain-lain Hak yang Timbul dari Hak Milik, Bandung: TARSITO Bandung

\section{Internet}

[1] https://www.pikiran-rakyat.com/pendidikan/pr-01281064/41-juta-anakindonesia-tidak-sekolah402455\#: : :text=JAKARTA\%2C\%20(PR).,6\%2D21\%20tahun\%20tidak\%20s ekolah, accessed on 12 May 2021.

[2] https://finance.detik.com/energi/d-5511928/awas-hoax-bbm-langkaimbas-kilang-kebakaran-pertamina-stokluber? ga=2.97229085.383504003.1617111994-2108725843.1615290580, accessed on 12 March 2021.

[3] https://www.jawapos.com/nasional/06/02/2021/polri-sepanjang-2020ada-352-kasus-hoax/, accessed on 12 March 2021.

[4] Fransiskus Sebastian Situmorang, (2017), Tinjauan Yuridis Terhadap Kententuan Pasal 28 ayat 2 UU informasi dan tekhnologi, https://ojs.unud.ac.id 